\title{
Unacylated ghrelin binds heparan-sulfate proteoglycans which modulate its function
}

\author{
Patric J D Delhanty, Martin Huisman, Karina Prins, Cobie Steenbergen, Rosinda Mies, Sebastian J C M M Neggers, \\ A J van der Lely and Jenny A Visser
}

Laboratory of Metabolism and Reproduction, Department of Internal Medicine, Erasmus MC, University Medical Center Rotterdam, Rotterdam, The Netherlands

Correspondence should be addressed to P J D Delhanty: p.delhanty@erasmusmc.nl

\begin{abstract}
Acylated ghrelin (AG) is a gut-derived peptide with growth hormone secretagogue (GHS), orexigenic and other physiological activities mediated by GHS receptor-1a (GHSR). Ghrelin occurs in unacylated form (UAG) with activities opposing AG, although its mechanism of action is unknown. UAG does not antagonize AG at GHSR, and has biological effects on cells that lack this receptor. Because UAG binds to cells, it has been hypothesized that UAG acts via a cell-surface receptor, although this has not been confirmed. This study aimed to identify cell surface proteins to which UAG binds that could modulate or mediate its biological effects. The MCF7 cell-line was used as a model because UAG induces ERK signaling in these cells in the absence of GHSR. Using ligand-receptor capture and LC-MS/MS we identified specific heparan-sulfate proteoglycans (HSPGs) to which UAG interacts on cell surfaces. In line with this, UAG, as well as AG, bind with high affinity to heparin, and heparin and heparinase treatment suppress, whereas HSPG overexpression increases, UAG binding to MCF7 cell surfaces. Moreover, heparin suppresses the ERK response to UAG. However, conversion of the lysines in UAG to alanine, which prevents its binding to heparin and cell surface HSPGs, does not prevent its activation of ERK. Our data show that the interaction of UAG with HSPGs modulates its biological activity in cells. More broadly, the interaction of UAG and AG with HSPGs could be important for the specificity and potency of their biological action in vivo.
\end{abstract}

\section{Key Words}

- extracellular-signalregulated kinase (ERK)

- heparin-binding protein

- heparan-sulfate proteoglycan (HSPG)

- heparin

- cell-surface protein

- peptide hormone

- ghrelin

- unacylated

- ligand-receptor capture
Journal of Molecular Endocrinology (2021) 66, 83-96

\section{Introduction}

Kojima et al. (1999) discovered the acylated peptide ghrelin (AG) by monitoring the effects of stomach extracts on calcium concentration in cells expressing the previously described growth hormone secretagogue receptor 1a (GHSR). Ghrelin is a 28 amino acid peptide in humans, with minor variations in length and sequence in other mammals. Ghrelin and its receptor probably originated during chordate evolution (Tine et al. 2016) and so far has only been described in vertebrates. In their seminal study, Kojima et al. also showed that the non-acylated form of ghrelin (UAG) did not activate GHSR in the physiological, low nanomolar, concentration range. Subsequent in vitro and in vivo studies showed that UAG can activate the GHSR (Gauna et al. 2007, Heppner et al. 2014), but that this only occurs when the peptide is at supraphysiological concentrations. A bulky hydrophobic moiety (usually an octanoyl group) must be attached to the third amino acid residue (Ser3) of the peptide for full potency at GHSR (Bednarek et al. 2000, Gauna et al. 2007). 
Acylated ghrelin is a potent growth hormone secretagogue and is upregulated by fasting. Its main biological function is to protect against starvationinduced hypoglycemia (Goldstein et al. 2011). This effect is mediated by growth hormone which induces hepatic gluconeogenesis subsequently maintaining glycemic levels above those required for survival (Goldstein et al. 2011, Fang et al. 2019). In relation to this, ghrelin regulates insulin sensitivity and insulin secretion (Broglio et al. 2001). AG is also the only known circulating orexigenic hormone (Muller et al. 2015). In addition to the well-characterized biological activities of AG there is evidence of a biological role for UAG. Studies that describe the biological activity of UAG seem to show that it particularly targets the metabolic effects of AG, for example on glucose homeostasis (Broglio et al. 2004, Gauna et al. 2005, Benso et al. 2012, Delhanty et al. 2013). UAG, however, does not antagonize AG at its receptor (Gauna et al. 2007), and antagonists of the GHSR do not necessarily have anti-diabetogenic actions (Halem et al. 2005, Costantini et al. 2011). Furthermore, UAG has effects on the biological functions of cells that do not express the GHSR (Cassoni et al. 2001). Despite this, UAG has been found to bind to cells with relatively high affinity (Cassoni et al. 2001, 2004) suggesting the presence of receptors or other interacting proteins on the cell surface. This has led to the hypothesis that UAG acts via an uncharacterized cell surface receptor (Callaghan \& Furness 2014). However, attempts to identify a receptor, as of writing for nearly 20 years, has been without success. Our aim was to characterize the interaction between UAG and cell surfaces in more detail as a step toward characterizing its mode of signal transduction.

Here, we show that a cell line that lacks expression of GHSR and other components of the ghrelin system, ghrelin and ghrelin O-acyl transferase (GOAT), responds consistently to treatment with UAG via the ERK signaling pathway. Using these cells we used ligand-receptor capture (LRC) and LC MS/MS (Frei et al. 2013) to identify cell surface proteins with which UAG interacts. We show that the main interactors are a group of heparan sulfate proteoglycans (HSPGs) to which UAG (and the structurally similar AG) bind, and that modulation of this interaction affects the biological response to UAG.

\section{Materials and methods}

\section{Cell culture}

MCF7 cells were grown in DMEM (ThermoFisher \#31966), $10 \%$ fetal calf serum (not-heat inactivated), penicillin/ streptomycin $(100 \mathrm{U} / \mathrm{mL})$ and passaged using TrypLE
Express enzyme (no phenol red). For experimental procedures, cells were seeded at $1.5 \times 10^{5}$ cells/well in six-well plates. After $24 \mathrm{~h}$ growth medium was replaced by starvation medium (DMEM with no phenol red (ThermoFisher \#31053), $2 \mathrm{mM}$ glutamine, $1 \mathrm{mM}$ sodium pyruvate, $0.1 \%$ BSA, $50 \mathrm{nM}$ estradiol, penicillin/ streptomycin). All experiments were performed on cells that had been grown for $48 \mathrm{~h}$ in starvation medium. The genotype of the MCF7 cell-line was confirmed by short tandem repeat DNA profiling verified using data available from ATCC.

\section{Transfections}

Expression plasmids (pCMV3) carrying cDNAs encoding C-terminally FLAG-tagged human SDC1 (NM_001006946.1), CD44 (BC004372) and GPC1 (NM_002081.2) as well as a control plasmid (pCMV3-CFLAG-NCV) were obtained from SinoBiological. A cDNA encoding full-length human NRP1 (AF016050; kindly provided by Drs Soker and Klagsbrun (Soker et al. 1998)) was PCR cloned (Li et al. 2011) into pCMV3-C-FLAG-NCV to obtain a construct encoding C-terminally FLAG-tagged NRP1. Twenty-four hours after seeding MCF7 cells at $4 \times 10^{5}$ cells/T25 flask, $1 \mu \mathrm{g}$ of plasmid was transfected using Fugene HD (Promega) and subsequently maintained in starvation medium for $48 \mathrm{~h}$ before FACS analysis.

\section{Peptides}

Acylated ghrelin (AG), unacylated ghrelin (UAG) and C-terminally biotinylated acylated ghrelin (AGbio) were obtained from Bachem (Switzerland). C-terminally biotinylated UAG and AG variants were synthesized by Biomatik (Ontario, Canada). See Table 1 for sequences. All peptides were obtained at $>95 \%$ purity, dissolved at $1 \mathrm{mM}$ in water and stored at $-20^{\circ} \mathrm{C}$.

\section{Western analysis}

Cells were seeded at $1.5 \times 10^{5}$ cells/well in six-well plates. After $24 \mathrm{~h}$ the growth medium was replaced by starvation medium. After $48 \mathrm{~h}$ medium was replaced by starvation medium containing treatments as indicated in 'Results' section. The medium was then replaced with $80 \mu \mathrm{L}$ of icecold lysis buffer (50 mM HEPES, pH 7.5, $150 \mathrm{mM} \mathrm{NaCl}$, $10 \mathrm{mM}$ EDTA, $2 \mathrm{mM} \mathrm{Na}_{3} \mathrm{VO}_{4}, 20 \mathrm{mM} \mathrm{NaF}, 1 \%$ Triton X-100, Protease/Phosphatase inhibitor cocktail (ThermoFisher, \#88669; 1 tablet/10 mL buffer)) and the plates were frozen 
Table 1 Sequences of biotinylated ghrelin variants used in the study.

UAGbio
UAG-4Abio
AGbio
AG-4Abio

GSSFLSPEHQRVQQRKESKKPPAKLQPR-(K-biotinyl)

GSSFLSPEHQRVQQRAESAAPPAALQPR-(K-biotinyl) GSS(octanoyl)FLSPEHQRVQQRKESKKPPAKLQPR-(C-BMCC-biotinyl) GSS(octanoyl)FLSPEHQRVQQRAESAAPPAALQPR-(K-biotinyl)

Biotinylated C-terminal lysines (K-biotinyl) lack positive charge.

on dry ice. After thawing, lysates were centrifuged and the protein content of the supernatants was measured (BioRad Protein Assay). Fifteen micrograms of protein was then run on Bolt $10 \%$ Bis-Tris Plus polyacrylamide gels (ThermoFisher) and transferred to nitrocellulose membranes. To simultaneously detect total and phosphoERK, specific rabbit and mouse antibodies (Cell Signaling Technology; \#9102 and \#9106, respectively) were combined at 1:2000 each in PBS containing 0.1\% Tween 20 and 3\% non-fat milk. Membranes were incubated overnight at $4^{\circ} \mathrm{C}$ and then washed extensively in PBS, $0.1 \%$ Tween 20 before being incubated for $1 \mathrm{~h}$ at room temperature in a mixture of anti-rabbit-IRDye 680RD and anti-mouse-IRDye 800CW (1:15000 each in PBS, 0.1\% Tween 20, 5\% non-fat milk). After extensive washing in PBS, 0.1\% Tween 20, membranes were scanned with an Odyssey CLx and images analyzed using Image Studio Lite (Li-Cor, NE, USA).

\section{FACS}

MCF7 cells were seeded at $4 \times 10^{5}$ cells/T25 flask in growth medium which was replaced after $24 \mathrm{~h}$ with starvation medium. After $48 \mathrm{~h}$ cells were detached with $1 \mathrm{~mL}$ PBS, 5 mM EDTA, pelleted at $425 \boldsymbol{g}$ and resuspended in staining buffer (PBS, $1 \%$ fetal calf serum, $\mathrm{pH}$ 6.8). Biotinylated peptides \pm unlabeled UAG were added $(3 \mu \mathrm{L})$ to $1.5 \mathrm{~mL}$ Eppendorf tubes followed by $195 \mu \mathrm{L}$ of cell suspension. The mixture was then incubated $1 \mathrm{~h}$ at $4^{\circ} \mathrm{C}$ then washed three times by centrifugation with ice-cold staining buffer. The pellet of cells was resuspended in $200 \mu \mathrm{L}$ of streptavidin-allophycocyanin (APC, Biolegend; diluted to $0.4 \mu \mathrm{g} / \mathrm{mL}$ in staining buffer) and incubated on ice for $30 \mathrm{~min}$. After a wash step, the cell pellet was resuspended in $50 \mu \mathrm{L}$ of staining buffer and FACS was performed with an Accuri C6 cytometer (Beckton-Dickinson). A similar procedure was used when staining for cell surface heparan sulfates, except that peptides were substituted for the anti-HS MAB 4E10 (Amsbio, Abingdon, UK; $2 \mu \mathrm{L}$ of 1:100 per tube) and anti-mouse-IgM-phycoerythrin conjugate (Biolegend; $2.5 \mu \mathrm{g} / \mathrm{mL}$ ) was used for detection. For heparinase treatment, MCF7 cells were resuspended at $1 \times 10^{6}$ cells $/ 100 \mu \mathrm{L}$ in FACS buffer then added to tubes containing $50 \mathrm{mIU}$ of heparinase III (EC 4.2.2.8; Amsbio) and incubated at $4^{\circ} \mathrm{C}$ for $1 \mathrm{~h}$.

\section{Ligand-receptor capture (LRC)-TriCEPS}

The LRC-TriCEPS protocol was performed as recommended by the manufacturer (Frei et al. 2013). Briefly, two coupling reactions were prepared, one to label the control ligand, transferrin, and the other to label UAG with the trivalent TriCEPS cross-linker to available lysines. $1.2 \times 10^{8} \mathrm{MCF} 7$ cells, grown in starvation medium/E2 for $48 \mathrm{~h}$, were resuspended in PBS. Cell surface carbohydrates were oxidized with 1.5 $\mathrm{mM} \mathrm{NaIO}_{4}$ for $15 \mathrm{~min}$, then the cells were washed in LRC buffer (PBS, pH 6.8, 1\% FBS) and divided into two separate tubes. The TriCEPS labeled transferrin and UAG were then added individually into each tube and incubated at $4^{\circ} \mathrm{C}$ for $90 \mathrm{~min}$ on a rotator. Cells were then centrifuged and cell pellets resuspended in $3 \mathrm{~mL}$ of LRC buffer and split into three times $1.5 \mathrm{~mL}$ Eppendorf tubes. The cells were pelleted by centrifugation and the pellets stored at $-80^{\circ} \mathrm{C}$. Cell pellets were then sent to Dual Systems for glycopeptide affinity purification and LC-MS/MS-based (Thermo LTQ Orbitrap $\mathrm{XL}$ ) identification of tryptic peptides (data available via ProteomeXchange with identifier PXD022761). The six samples were analyzed as follows. Progenesis was used for raw file alignment and feature detection, the Comet search engine for spectra identification and the Trans proteomic pipeline for statistical validation of putative identifications and protein inference. Relative quantification of control and UAG samples was performed based on ion extracted intensity, and differential protein abundance was tested by ANOVA followed by multiple testing correction. The model assumed measurement error followed a Gaussian distribution and viewed individual features as replicates of a protein's abundance and explicitly accounts for this redundancy. It tests each protein for differential abundance in all pairwise comparisons of ligand and control samples and reports the $P$-values. Next, $P$-values were adjusted for multiple comparisons to control the experiment-wide false discovery rate (FDR). The adjusted $P$-value (q-value) obtained for every protein was plotted against the magnitude of the fold enrichment between the two experimental conditions in a volcano plot. Criteria for selection of targets were 
proteins identified by at least two peptides and a $\log _{2}$-fold enrichment $>1$ with a $-\log _{10}$ (adjusted $P$-value) $>6$.

\section{FPLC (heparin-sepharose)}

Biotinylated UAG variants (Biomatik; Table 1) were dissolved in buffer A (50 mM Tris, pH 7) at $10 \mu \mathrm{g} / 200 \mu \mathrm{L}$ which was then loaded onto an FPLC system (Pharmacia, GP250) connected to a $1 \mathrm{~mL}$ heparin-sepharose column (HiTrap heparin HP; GE Healthcare). The conversion of the lysines to alanines in the AG-4Abio variant of AG made the peptide much less soluble in aqueous buffer, presumably because of its markedly reduced overall hydrophilicity. Dot blots were used to assess the relative amount of peptide in solution and based on this, a similar amount of peptide was loaded onto the column. The column was washed with five column volumes of buffer A, then column elution was carried out using a linear 0-2 $\mathrm{M} \mathrm{NaCl}$ gradient of 15 column volumes. Fifteen 1 $\mathrm{mL}$ fractions were collected and $2 \mu \mathrm{L}$ samples from each fraction were screened on westerns using streptavidinIRDye $800 \mathrm{CW}$. Westerns were subsequently scanned using an Odyssey CLx and quantified with Image Studio software (Li-Cor).

\section{Gene expression (RNASeq and QPCR)}

MCF7 cells were treated for $48 \mathrm{~h}$ with $\mathrm{E} 2$ in six-well plates, then total RNA was isolated from three samples using a procedure similar to that previously described (Delhanty et al. 2010, van den Beukel et al. 2014). RNA integrity was confirmed using an RNA 6000 Nano bioanalyzer (Agilent). RNASeq analysis was performed at the ErasmusMC Center for Biomics (data available at SRA accession PRJNA672475). Quantitative PCR (QPCR) was performed with gene-specific primers designed using PrimerBLAST whose amplicons crossed intron-exon boundaries (hMBOAT4-F, CAGGTGGACCTTCTGCTTTCA; hMBOAT4-R, GCCTTCACTTTCCCCTCACAA; hGHRL-F, TCAGGGGTTCAGTACCAGCA; hGHRL-R, CAAGCGAAAAG CCAGATGAG; hGHSR1a-F, CCAGAACCACAAGCAAACCG; hGHSR1a-R, AAAGGACACGAGGTTGCAGT; hGPC1-F, CGAGGTCCGCCAGATCTAC; hGPC1-R, AGGTTCTCCTC CATCTCGCT; hNRP1-F, ATGACGACCAGGCCAACTG; hNRP1-R, ATGACCGTGGGCTTTTCTGT; hSDC1-F, CAG CTCCCGAAAGCGACG; hSDC1-R, CTCTCTACTGCCGG ATTCCT; hCD44-F, GGGATATCGCCAAACACCCA; hC D44-R, TGGATGGCTGGTATGAGCTG; h36b4-F, TCTA CAACCCTGAAGTGCTTGAT; h36b4-R, CAATCTGCAGA CAGACACTGG).

\section{Statistical analyses}

In all cases, analyses were performed on at least three biological replicate experiments. All graphing and analysis of FACS and Western data were performed using Graphpad Prism v.5. One-way ANOVA was used for multiple comparisons with a $P$-value $\leq 0.05$ used as an indicator of significant difference. A description of the statistical approach used to analyze the ligand-receptor capture data are provided previously.

\section{Results}

\section{Characterization of a UAG-responsive cell line that lacks the ghrelin receptor}

Our aim was to find a cell line that lacked expression of GHSR but that responded to UAG. An early study by Cassoni et al. (2001) suggested that the breast cancer cell line MCF7 matched these characteristics since it lacks GHSR gene expression, but binds UAG. Moreover, UAG suppresses estradiol-dependent growth of MCF7 cells in 2D and 3D culture (Cassoni et al. 2001, Au et al. 2020). Because of these findings, we have used MCF7 cells as a model to investigate how UAG interacts with these cells and generates a biological response. In initial experiments, we confirmed the absence of expression of GHSR, GHRL and MBOAT4 (GOAT) in our MCF7 cell-line by quantitative reverse transcriptase PCR (Fig. 1A).

Since transient induction of ERK signaling has been demonstrated to mediate estrogen-dependent suppression of MCF7 cell growth in 2D cultures (Zheng et al. 2007), the acute effects of UAG treatment on ERK activation (phosphorylation) was used as a read-out of biological activity of UAG in these cells. MCF7 cells were cultured in medium without serum but with estradiol for $48 \mathrm{~h}$ and then treated with $100 \mathrm{nM}$ UAG for $5 \mathrm{~min}$. Western blot analysis of total cell lysates showed a marked effect on ERK phosphorylation. Time-course experiments showed that the ERK response to UAG is rapid and transient, peaking at $5 \mathrm{~min}$ then declining to baseline again by $60 \mathrm{~min}$ after treatment (Fig. 1B). This response is also dose-dependent reaching a plateau at 10-100 nM (Fig. 1C).

\section{Identification of cell surface UAG binding partners by ligand-receptor capture (LRC)}

To assess the binding of UAG, MCF7 cells were cultured with estradiol in the absence of serum. Initially, we used C-terminally biotinylated UAG and streptavidinconjugated phycoerythrin (PE) to measure binding to 


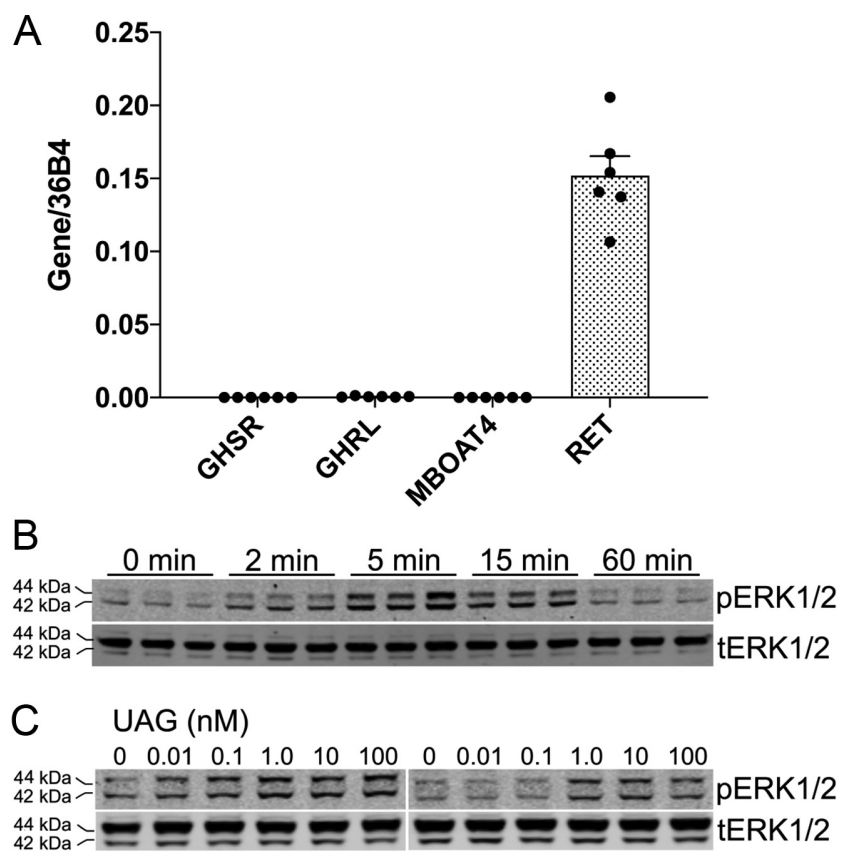

Figure 1

UAG activates ERK signaling in MCF7 cells in the absence of expression of GHSR. (A) GHSR, GHRL and MBOAT4 (GOAT) mRNAs are not expressed in MCF7 cells. Expression of mRNAs assessed by RT-QPCR $(n=6)$. (B) Time course of response to UAG. A representative western of proteins from MCF7 cells treated for different time periods with 100 nM UAG screened simultaneously for phospho and total ERK1/2 (similar results were obtained in four separate experiments). The maximal response occurs at 5 min. (C) Dose-response to UAG. Two representative Western blots of proteins from MCF7 cells treated for 5 min with different concentrations of UAG screened simultaneously for phospho and total ERK1/2 (similar results were obtained in four separate experiments). Response reaches plateau at 10-100 nM UAG.

live cells using flow cytometry (Fig. 2A). This approach demonstrated the binding of UAG to MCF7 cells, as observed in an earlier study using radiolabeled peptides (Cassoni et al. 2001). Cells were labeled while incubating in ice-cold buffers to prevent internalization of the biotinylated UAG. Similar results were obtained in experiments performed with cells treated with cytochalasin D (data not shown) indicating that apparent binding cannot be explained by internalization of UAG.

Since serum-starved, estradiol treated MCF7 cells consistently bound UAG as assessed by FACS, we decided to use this cell-line to identify cell-surface binding partners/receptors for UAG using the ligand-receptor capture approach (Frei et al. 2013). The tri-partite linker molecule LRC-TriCEPS was used to isolate UAGinteracting proteins which were identified by tandem mass spectrometry. Transferrin was used as a control ligand to exclude non-specific interactions of TriCEPS. Binding of TriCEPS-conjugated UAG showed similar characteristics to that of biotinylated UAG, as assessed by FACS (Fig. 2B). Fluorescence microscopy of cells prepared for FACS with TriCEPS-phycoerythrin-conjugated UAG demonstrated cell-surface fluorescence, indicative of cell surface binding (Fig. 2C).

Analysis of captured peptides identified several interacting proteins, four, in particular, exhibiting the greatest abundance and number of tryptic peptides in UAG complexes (Fig. 2D). These included syndecan-1 (SDC1), glypican-1 (GPC1), CD44 and neuropilin-1 (NRP1). All are members of the heparan sulfate proteoglycan (HSPG) family of proteoglycans, although CD44 and NRP1 are classified as part-time HSPGs, since they are not constitutively post-transcriptionally modified with heparan sulfate chains in all cell types (Mythreye \& Blobe 2009, Sarrazin et al. 2011, Xu \& Esko 2014). The expression of all four genes in MCF7 cells was confirmed by quantitative reverse-transcriptase PCR (Fig. 2E) and RNASeq (Table 2). Interestingly, the RNASeq data show that GPC4, GPC6 and SDC4 were expressed at nearly equivalent levels as the four interacting HSPGs but were not identified by LRCTRICEPS, suggesting preferential binding to specific HSPGs. The RNASeq data also demonstrate that the MCF7 cells express mRNAs for many of the enzymes involved in HS biosynthesis.

\section{UAG is a heparin-binding peptide}

The finding that UAG binds to HSPGs suggested the involvement of a charge-based interaction with the glycan sugars on these proteoglycans. To test this, we first examined the ability of UAG to bind to heparin. Heparin is generally similar in structure to heparan sulfates but carries a markedly greater density of negatively charged sulfates (Xu \& Esko 2014). A heparin-sepharose FPLC column was loaded with biotinylated human UAG then eluted with a linear gradient of $\mathrm{NaCl}$ solution ranging from 0 to $2 \mathrm{M}$. UAG was eluted at a $\mathrm{NaCl}$ concentration of approximately $800 \mathrm{mM}$, indicating a high-affinity charge-dependent interaction (Fig. 3A).

UAG contains four conserved lysines in its C-terminal region (residues 16, 19, 20 and 24). Since the complex formation between other known HS binding proteins (HSBPs) and HS are dependent on electrostatic interactions (Xu \& Esko 2014), it was reasoned that these lysines may be involved in the binding of UAG to heparin. Substitution of the four lysines for alanines (UAG-4A, Table 1) abrogated binding of UAG to heparin-sepharose columns (Fig. 3B). 

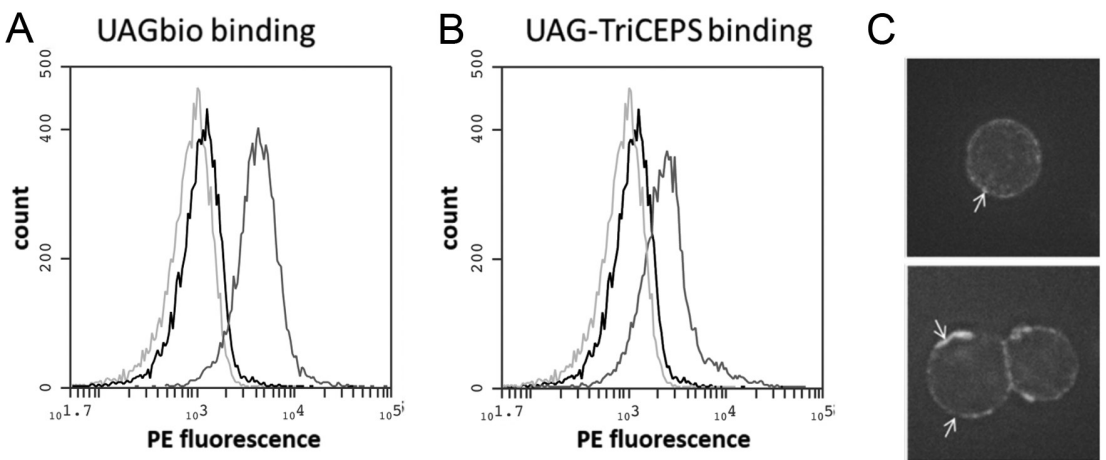

E
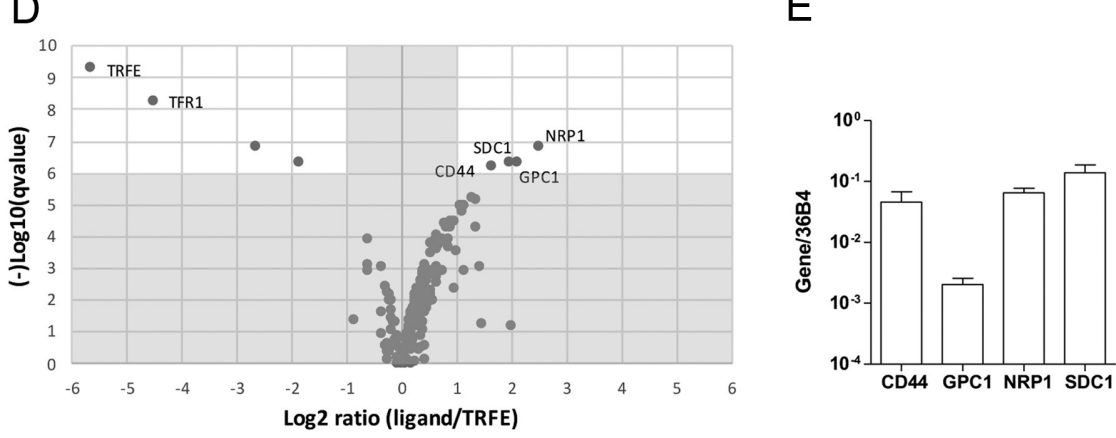

Figure 2

Identification of cell surface UAG-interacting proteins. (A) Representative FACS plot showing UAGbio binding to the surfaces of MCF7 cells (pale grey, unstained; black, PE-streptavidin stained; grey, $2 \mu \mathrm{M}$ UAGbio). (B) Binding of UAG-TriCEPS conjugates to MCF7 cells (pale grey, unstained; black, PE-streptavidin stained; grey, 2 uM PE-TriCEPS-UAG). (C) Fluorescence micrographs of PE-TriCEPS-UAG bound to MCF7 cell surfaces. (D) Identification of UAG-interacting proteins by ligand-receptor capture (LRC). Data are represented in a volcano plot. The $\mathrm{x}$-axis represents the mean ratio fold change $\left(\log _{2}\right.$ scale) in enrichment (UAG/transferrin binding) and the $y$-axis represents the significance (q-value) of that change. Proteins enriched in the control (transferrin) fraction plot to the left of the $\mathrm{x}$-axis origin, whereas proteins enriched in the UAG fraction plot to the right. Using stringent $x$ and $y$ cutoffs ( $\log _{2}$ ligand/TRFE ratio of 1 and a q-value of 6), four UAG-interacting proteins were identified: CD44, GPC1, NRP1 and SDC1. TRFE and TFR1 are transferrin and transferrin receptor 1. (E) Relative expression of HSPG mRNAs in MCF7 cells assessed by RT-QPCR $(n=4)$.

\section{Characterization of UAG binding to MCF7 cells}

We next explored in more detail the nature of the interaction between UAG and MCF7 cells. C-terminally biotinylated UAG was used as a probe to measure binding to live cells using flow cytometry. Using this approach, we found that UAG bound to the cells dose-dependently, with binding detectable in the $100 \mathrm{nM}$ range. However, binding was not saturable up to $200 \mu \mathrm{M}$ (Fig. 4A and B) and we were unable to reliably competitively displace biotinylated UAG with excess unlabeled UAG (Fig. 4C and D).

To determine if cell surface HSPGs contribute to UAG surface binding to MCF7 cells, several experimental approaches were used. Firstly, MCF7 cells were transiently transfected with plasmids encoding FLAGtagged HSPGs and UAGbio binding was assessed by FACS. Overexpression of the HSPGs tended to increase UAGbio binding (Fig. 5A), although this effect was only significant for SDC1 and GPC1. SDC1 and GPC1 are 'fulltime' HSPGs whose function is restricted to HS effects on cell-signaling (Knelson et al. 2014). Expression of the FLAG-tagged HSPGs was confirmed by Western blot using anti-FLAG antibodies (Fig. 5B). Heparin has been demonstrated to regulate the binding of ligands to cell surface receptors, particularly to modify the binding of heparin-binding proteins. We, therefore, first assessed the ability of heparin in a range of concentrations
$(0.1-100 \mu \mathrm{g} / \mathrm{mL})$ to modulate the binding of UAGbio to MCF7 cells. Heparin suppression of UAGbio binding was maximal at $100 \mu \mathrm{g} / \mathrm{mL}$ (Fig. 5C).

In an alternative experimental approach, we tested the effect of reducing the density of MCF7 cell surface heparan sulfates by treating them with heparinase III (EC 4.2.2.8) which cleaves heparan sulfate chains exclusively. FACS analysis, using a MAB specific for $\mathrm{N}$-sulfated glucosamine residues (10E4), demonstrated enzymatic removal of $84 \pm 3 \%$ of cell surface heparan sulfates $(P<0.001)$ (Fig. 6A and $\mathrm{B})$. Concomitantly with the removal of cell surface heparan sulfates, UAGbio binding was reduced by $49 \pm 6 \%$ $(P<0.001)$ (Fig. 6C and D).

Since the C-terminal lysines are critical for binding of UAG to heparin, we next determined their involvement in UAG binding to MCF7 cells. We found that even at $20 \mu \mathrm{M}$ biotinylated UAG-4A had significantly reduced binding to MCF7 cells (Fig. 6E and F). We also examined if the truncated peptide $\mathrm{UAG}_{6-13}$ was able to bind cells. We tested two biotinylated forms, one biotinylated via a C-terminal lysine (AZP502-bio) and another biotinylated at both $\mathrm{N}$ - and C-termini (bio-AZP502-bio). We were unable to detect cell surface binding with either peptide, even at $20 \mu \mathrm{M}$ (Supplementary Fig. 1A, see section on supplementary materials given at the end of this article). This corresponded with their complete lack of binding to heparin-sepharose columns from which they were eluted in the flow-through fractions (Supplementary Fig. 1B). 
Table 2 Expression levels of mRNAs encoding membrane-bound HSPGs and HS biosynthetic enzymes in MCF7 cells.

\begin{tabular}{|c|c|c|c|c|}
\hline & Gene name & Gene ID & Expression & S.E.M. \\
\hline \multicolumn{5}{|l|}{ Membrane bound HSPGs } \\
\hline CD44 & CD44 & ENSG00000026508 & 2267 & 63 \\
\hline \multirow[t]{6}{*}{ Glypicans } & GPC1 & ENSG00000063660 & 815 & 128 \\
\hline & GPC2 & ENSG00000213420 & 39 & 1 \\
\hline & GPC3 & ENSG00000147257 & 28 & 7 \\
\hline & GPC4 & ENSG00000076716 & 587 & 35 \\
\hline & GPC5 & ENSG00000179399 & 0 & 0 \\
\hline & GPC6 & ENSG00000183098 & 289 & 36 \\
\hline \multirow[t]{2}{*}{ Neuropilins } & NRP1 & ENSG00000099250 & 2254 & 97 \\
\hline & NRP2 & ENSG00000118257 & 21 & 1 \\
\hline \multirow[t]{4}{*}{ Syndecans } & SDC1 & ENSG00000115884 & 1759 & 137 \\
\hline & SDC2 & ENSG00000169439 & 391 & 20 \\
\hline & SDC3 & ENSG00000162512 & 685 & 49 \\
\hline & SDC4 & ENSG00000124145 & 2803 & 51 \\
\hline Betaglycan & TGFBR3 & ENSG00000069702 & 42 & 1 \\
\hline \multicolumn{5}{|l|}{ HS biosynthesis } \\
\hline \multirow[t]{2}{*}{ Galactosyltransferases } & B3GALT6 & ENSG00000176022 & 282 & 21 \\
\hline & B4GALT7 & ENSG00000027847 & 297 & 21 \\
\hline \multirow[t]{2}{*}{ HS copolymerases } & EXT1 & ENSG00000182197 & 424 & 5 \\
\hline & EXT2 & ENSG00000151348 & 544 & 17 \\
\hline $\mathrm{N}$-acetylglucosaminyl transferase-1 & EXTL3 & ENSG00000012232 & 523 & 32 \\
\hline Uronyl C5 epimerase & GLCE & ENSG00000138604 & 644 & 42 \\
\hline Heparanase & HPSE & ENSG00000173083 & 74 & 4 \\
\hline Uronyl-2-O-sulfotransferase & HS2ST1 & ENSG00000153936 & 565 & 70 \\
\hline \multirow[t]{7}{*}{ Glucosaminyl-3-O-sulfotransferases } & HS3ST1 & ENSG00000002587 & 2 & 1 \\
\hline & HS3ST2 & ENSG00000122254 & 0 & 0 \\
\hline & HS3ST3A1 & ENSG00000153976 & 140 & 13 \\
\hline & HS3ST3B1 & ENSG00000125430 & 170 & 12 \\
\hline & HS3ST4 & ENSG00000182601 & 0 & 0 \\
\hline & HS3ST5 & ENSG00000249853 & 52 & 6 \\
\hline & HS3ST6 & ENSG00000162040 & 1 & 0 \\
\hline \multirow[t]{3}{*}{ Glucosaminyl-6-O-sulfotransferases } & HS6ST1 & ENSG00000136720 & 1176 & 73 \\
\hline & HS6ST2 & ENSG00000171004 & 122 & 14 \\
\hline & HS6ST3 & ENSG00000185352 & 253 & 23 \\
\hline \multirow[t]{4}{*}{$\mathrm{N}$-deacetylase/N-sulfotransferases } & NDST1 & ENSG00000070614 & 1540 & 67 \\
\hline & NDST2 & ENSG00000166507 & 14 & 2 \\
\hline & NDST3 & ENSG00000164100 & 1 & 1 \\
\hline & NDST4 & ENSG00000138653 & 0 & 0 \\
\hline \multirow[t]{2}{*}{ Endo-6-sulfatases } & SULF1 & ENSG00000137573 & 2642 & 94 \\
\hline & SULF2 & ENSG00000196562 & 46,599 & 1100 \\
\hline \multirow[t]{2}{*}{ Xylosyltransferases } & XYLT1 & ENSG00000103489 & 310 & 9 \\
\hline & XYLT2 & ENSG00000015532 & 810 & 85 \\
\hline
\end{tabular}

Mean expression and S.E.M. of RNASeq data from three separate cultures of MCF7 grown in serum-free medium containing 50 nM E2 for 48 h.

Overall, these data demonstrate that removal of heparan sulfates with heparinase III significantly reduces UAG binding to MCF7 cells and identify a role for HSPGs in UAG cell surface binding. They also indicate the importance of electrostatic interactions via the C-terminal lysines which can be blocked by heparin.

\section{Acylated ghrelin binds to MCF7 cells and heparin}

Since AG has exactly the same peptide structure as UAG we also examined whether it can bind to MCF7 cells. We found a similar dose-dependent pattern of binding as UAG (Fig. 6G). Like UAG, biotinylated AG (AGbio, Table 1) bound to heparin-sepharose (Fig. 6H) and conversion of the C-terminal lysines to alanines (AG-4Abio, Table 1) almost completely abrogated binding (Fig. 6I).

\section{Modulation of the UAG-induced ERK response by interaction with heparin}

Because heparin and heparinase treatment suppress UAG binding to cell surfaces, we explored whether 
$\mathrm{A}_{\mathrm{kDa}}$

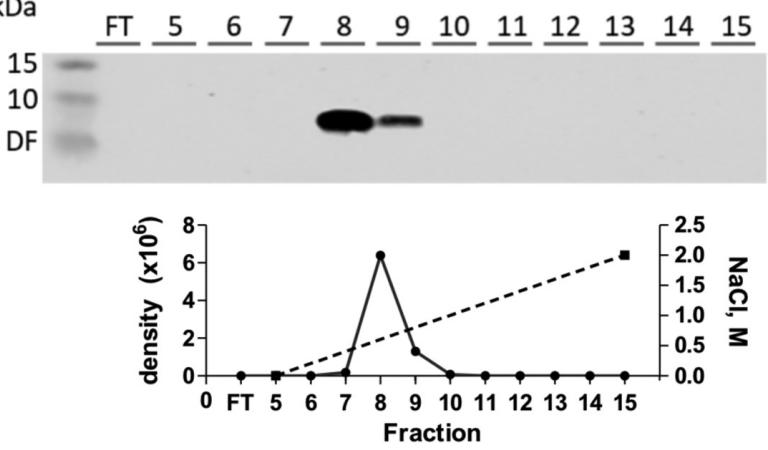

B kDa

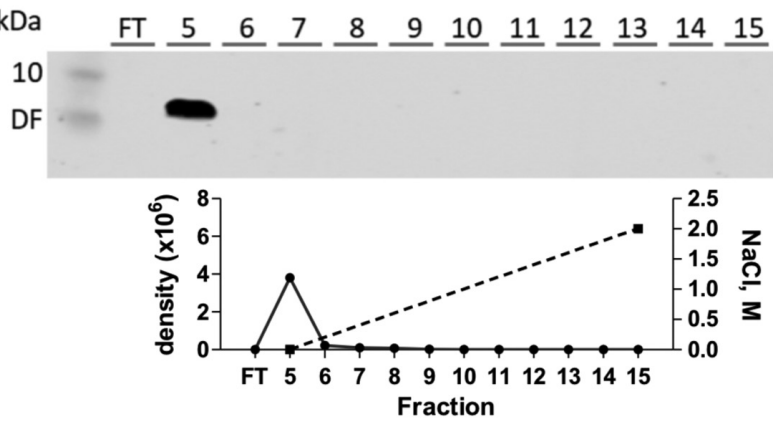

Figure 3

UAG is a heparin-binding protein. (A) Representative Western blot, and quantitation, of samples of fractions from a heparin-sepharose FPLC column ( $n=3$; DF, dye front). UAG biotin was loaded onto the column and fractions were eluted with a linear, 0-2 $\mathrm{M}$, gradient of $\mathrm{NaCl}$ (dotted line starting at fraction 5). UAG was consistently eluted at $\sim 800 \mathrm{mM} \mathrm{NaCl}$ $(n=3)$. (B) Lysine to alanine substituted UAG (UAG-4A) does not bind to heparin. A representative Western blot and quantitation of samples of fractions from a heparin-sepharose FPLC column is shown. UAG-4A biotin was loaded onto the column and fractions were eluted with a linear, 0-2 M, gradient of $\mathrm{NaCl}$ (dotted line starting at fraction 5). UAG-4A consistently eluted in the first fraction, not binding to the heparin-sepharose column $(n=3)$.

heparin treatment could modulate the ERK response of MCF7 cells to UAG. Our hypothesis was that heparin might interfere with UAG binding to the HSPGs and thus prevent signaling, perhaps by blocking electrostatic interactions with the lysines and sequestering UAG away from the cell surface. We tested a range of heparin concentrations ranging from 0.1 to $10 \mathrm{\mu g} / \mathrm{mL}$ together with $100 \mathrm{nM}$ UAG. Heparin dosedependently suppressed the ability of UAG to stimulate ERK phosphorylation (Fig. 7A).

Since the lysines in the C-terminus of UAG are required for binding to MCF7 cell surfaces via their heparan sulfates, we hypothesized that UAG peptides in which the lysines had been substituted for alanine (UAG-4A, Table 1) would be unable to stimulate an ERK phosphorylation response. On the contrary, we found that both forms of UAG generated the same level of response (Fig. 7B).
A
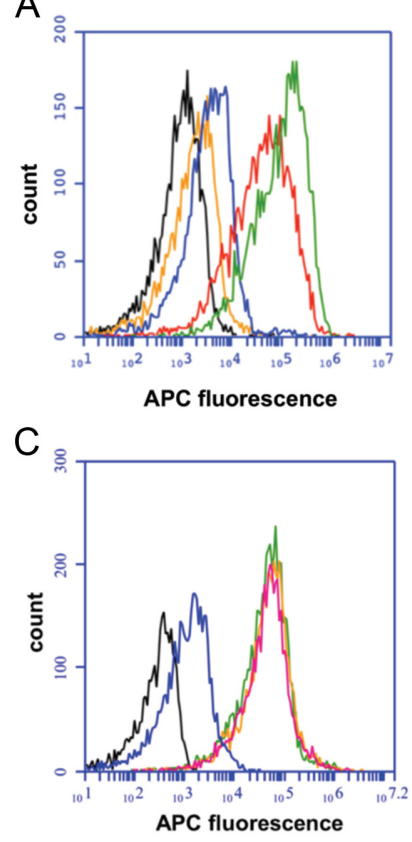

B
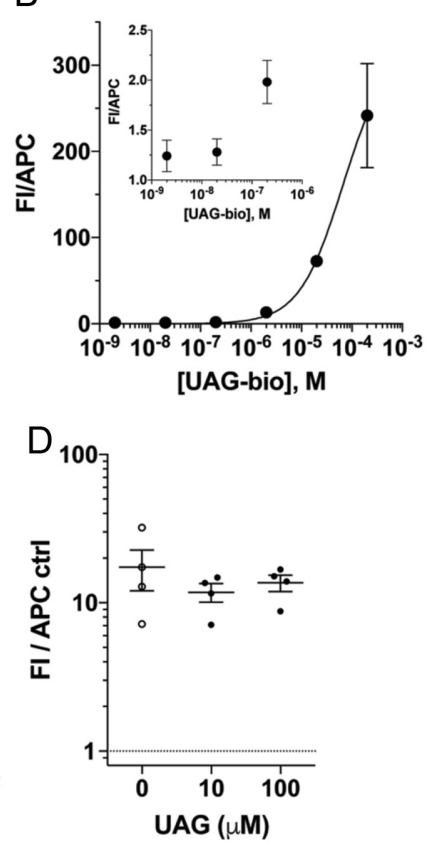

Figure 4

UAGbio binding to MCF7 cells is dose-dependent but high capacity/ unsaturable. (A) Representative FACS plot showing an experiment in which cells were incubated with 0-2 $\mu \mathrm{M}$ UAGbio detected with APCstreptavidin (black, APC-streptavidin; orange, $0.2 \mu \mathrm{M}$ UAGbio; blue, $2 \mu \mathrm{M}$ UAGbio; red, $20 \mu \mathrm{M}$; green, $200 \mu \mathrm{M}$ UAGbio). (B) Data expressed as median fluorescence intensity from cell-bound UAGbio detected by APC-streptavidin corrected for APC-streptavidin binding alone from $2 \mathrm{nM}-100 \mu \mathrm{M}$ UAGbio ( $n=4-7)$. Inset shows binding of UAG in the $\mathrm{nM}$ range. (C and D) Competition for UAGbio binding to cell surfaces with unlabeled UAG. (C) Representative FACS plot showing lack of competition by $5 \times$ and $50 \times$ molar excess of unlabeled UAG for $2 \mu \mathrm{M}$ biotinylated UAG (black, unstained; blue, APC-streptavidin; green, 2 $\mu \mathrm{M}$ UAGbio; orange, $2 \mu \mathrm{M}$ UAGbio + $10 \mu \mathrm{M}$ unlabeled UAG; red, $2 \mu \mathrm{M}$ UAGbio $+100 \mu \mathrm{M}$ unlabeled UAG). (D) Data expressed as median fluorescence intensity from cell-bound UAGbio detected by APC-streptavidin corrected for APC-streptavidin binding alone $(n=4)$.

\section{Discussion}

UAG binds to cells with relatively high affinity (Cassoni et al. 2001, 2004) indicating the presence of receptors or other interacting proteins on cell surfaces. However, so far, the identity of these interactors has not been elucidated. Our aim was to determine how UAG interacts with cell surfaces in more detail as a step toward identifying its mode of signal transduction. In this study, we report three main new findings: that UAG binds to a group of heparan sulfate proteoglycans (HSPGs) with which it interacts with high affinity at the cell surface; that this interaction is charge-dependent between lysines in UAG and heparan sulfate polysaccharide chains on cell surfaces; and that the biological effect (activation of ERK signaling in MCF7 cells) of UAG can be modulated 

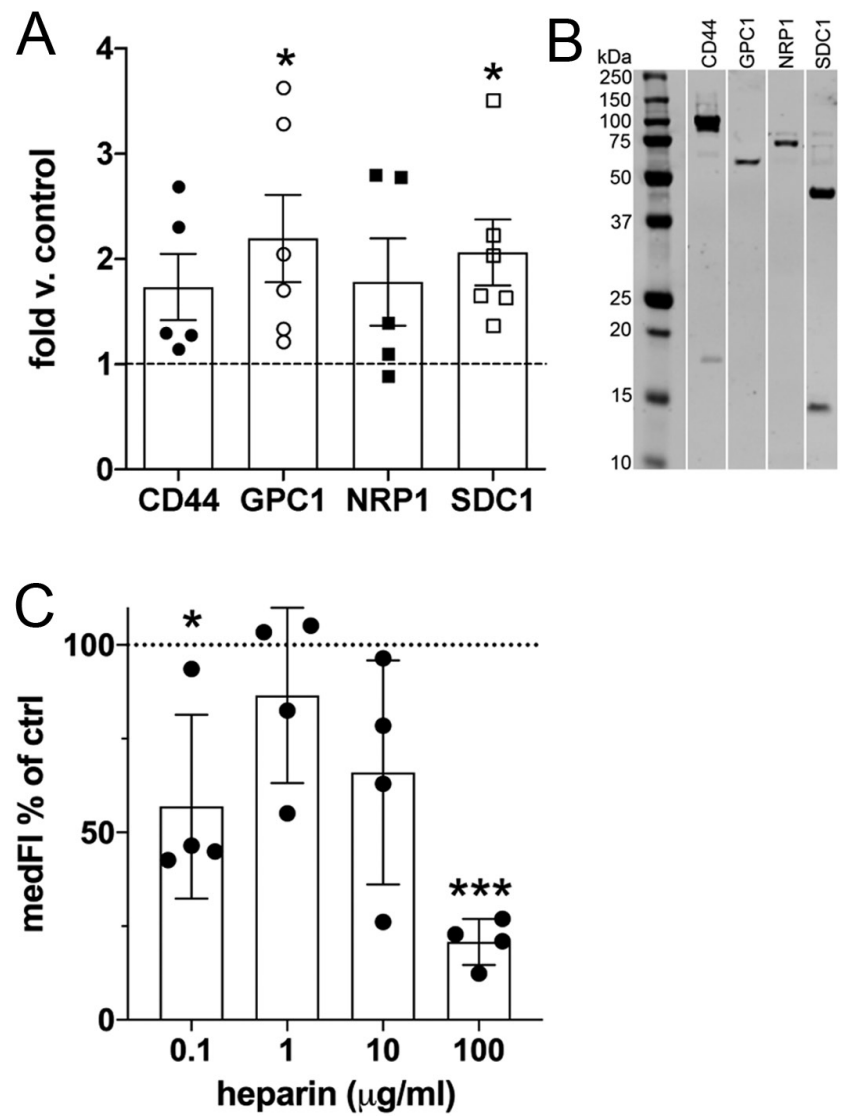

Figure 5

Binding of UAG to MCF7 cells is modulated by overexpression of HSPGs and heparin treatment. (A) Transient transfection of HSPGs modulates UAGbio binding assessed by FACS. Data expressed as fold increase in fluorescence relative to empty vector-transfected controls (median FI corrected for APC) ( $n=5$; * $P<0.05$ vs controls; 1 -sample t-test). (B) Representative Western blot of C-terminal FLAG-tagged HSPGs in transiently transfected MCF7 cells detected using anti-FLAG antibodies. (C) Heparin modulates binding of UAG to MCF7 cells. UAGbio binding to cells treated with different heparin concentrations (median fluorescence intensity) expressed as a percentage of binding to untreated controls ( $n=4 ; * P<0.05, * \star \star x<0.001$ vs control, ANOVA).

by heparin-mediated interference of its interaction with cell surface HSPGs.

As described previously, we confirm that UAG can stimulate the ERK signaling pathway in MCF7 cells in the absence of detectable GHSR gene expression (Cassoni et al. 2001). Together with rapid, dose-dependent activation of this pathway at nanomolar concentrations of UAG, below the threshold for activation of GHSR (Gauna et al. 2007), this indicates GHSR-independent signaling. The lack of ghrelin O-acyl transferase (GOAT) expression in these cells also suggests that extracellular UAG cannot be acylated in these cells. Conversion to AG has been suggested as a possible mode of UAG activation, but then via a GHSRdependent signaling mechanism (Hopkins et al. 2017).
GHRL mRNA is also not expressed in the MCF7 cell-line that we used.

Since our hypothesis is that UAG interacts with a cell surface receptor to activate ERK signaling, we used a FACS-based method to investigate this further. Biotinylated UAG was used as a probe for determining its interaction with the surfaces of MCF7 cells under conditions where internalization of cell surface molecules was blocked (Fig. 3). We then used ligandreceptor capture (LRC) with UAG bound to a tripartite cross-linking compound (TriCEPS) to identify cellsurface binding partners. Using this approach, it was determined that a group of four proteins, CD44, GPC1, NRP1 and SDC1 on MCF7 cell surfaces bound UAG. These are all members of the family of HSPGs (Sarrazin et al. 2011).

Heparan sulfates (HS) are linear polyanionic polysaccharide chains that are a member of a class of glycosaminoglycans (GAGs) that includes heparin (Bernfield et al. 1999). HS are covalently bound to serine residues that are part of GAG attachment sites on the protein core of the HSPG. HSPGs contain variable numbers of GAG attachment sites and, together with variability in HS chain length, this contributes to the heterogeneity of proteoglycan structure. CD44, GPC1, NRP1 and SDC1 each carry several GAG attachment sites, although CD44 and NRP1 are classified as part-time HSPGs since they are not constitutively decorated with heparan sulfates in all cell types (Sarrazin et al. 2011). It is possible that the lower density of HS on these latter HSPGs leads to the lower level of attachment of UAG to cells overexpressing CD44 and NRP1.

The finding that UAG binds to members of a family of HSPGs suggested that it is an HS binding protein (HSBP), whose main characteristics are the ability to bind heparin at physiologically relevant $\mathrm{pH}$ and salt concentrations ( $\mathrm{Xu} \&$ Esko 2014). UAG binds to heparin not only in physiological $\left(\sim 140 \mathrm{mM} \mathrm{Na}^{+}\right)$, but also supraphysiological (up to $\sim 800 \mathrm{mM}$ ) salt concentrations. HS are highly anionic and contribute a marked portion of binding free energy toward the interaction, predominantly between their charged sulfates and lysine and arginine residues, as well as polar residues such as histidine, in the HSBP. Such electrostatic interactions are a general characteristic that drives the formation of HSBP-HS complexes (Xu \& Esko 2014). We found that substitution of the C-terminal lysine residues of UAG for alanines completely abrogated binding to heparinsepharose columns and markedly suppressed binding to MCF7 cells. Residual binding to MCF7 cells could either 
A Cell surface heparan sulfates
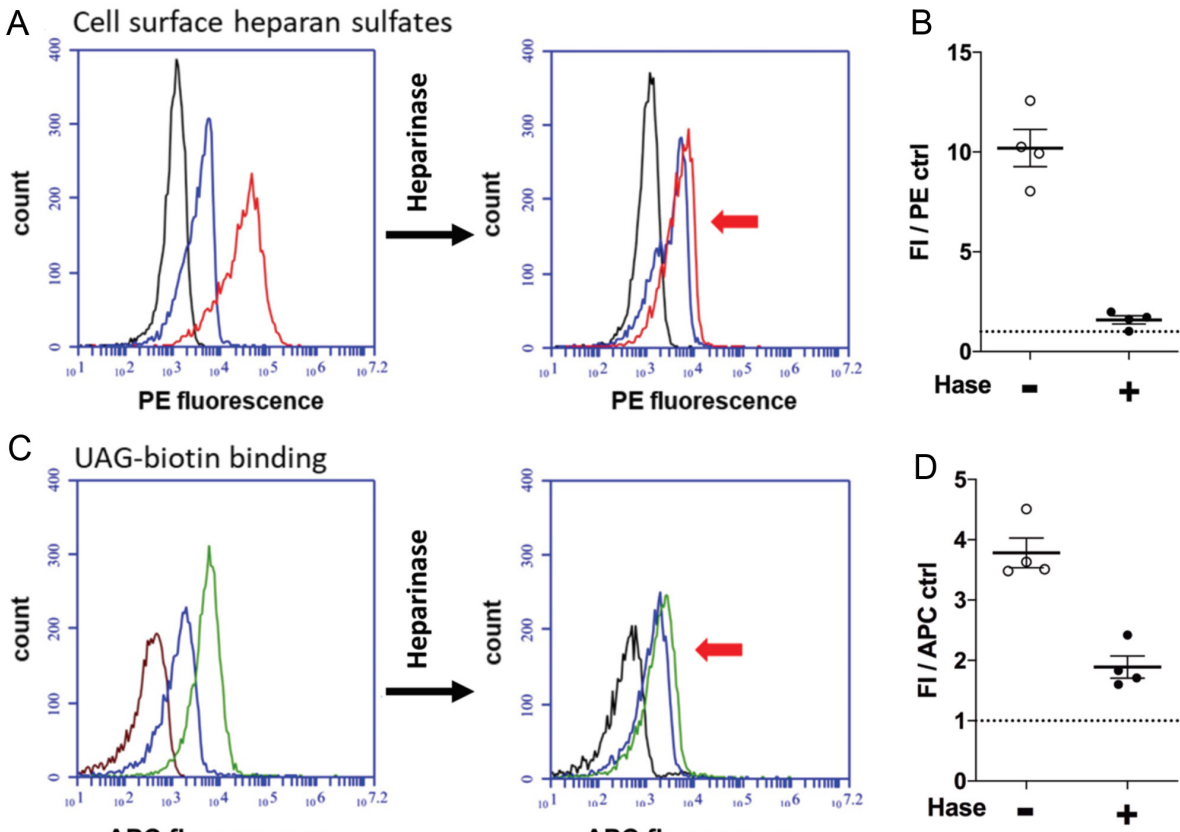

APC fluorescence

APC fluorescence

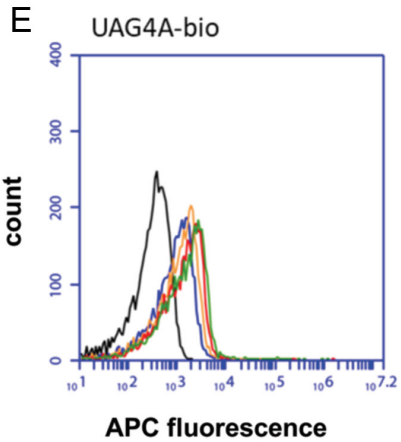

F

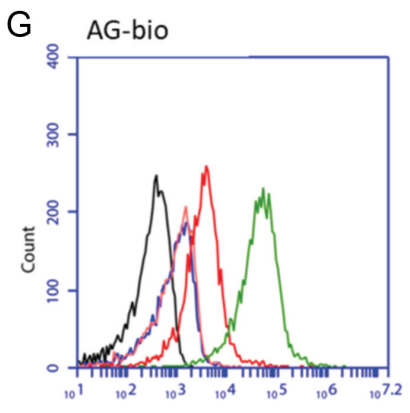

APC fluorescence
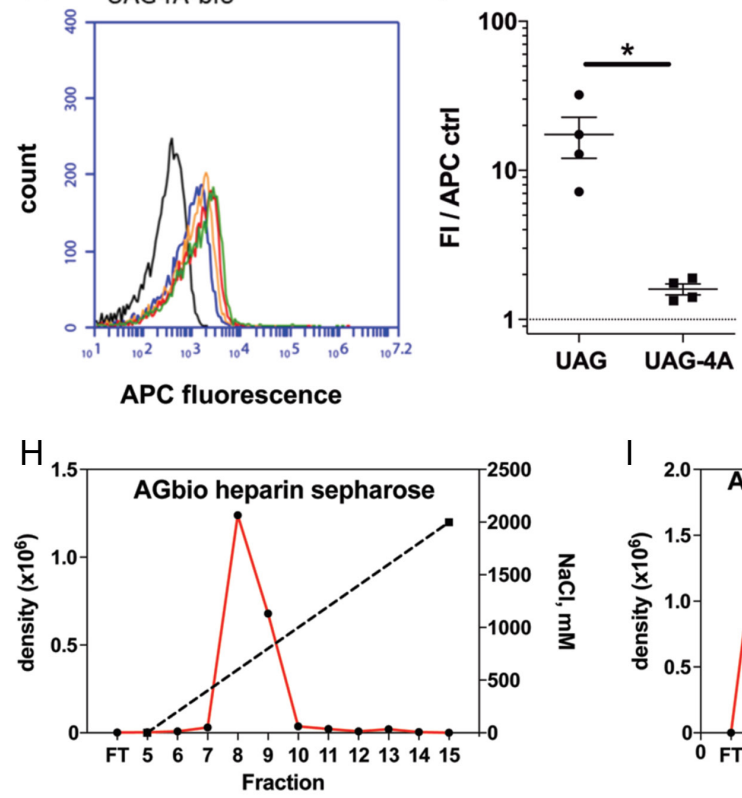

APC fluorescence

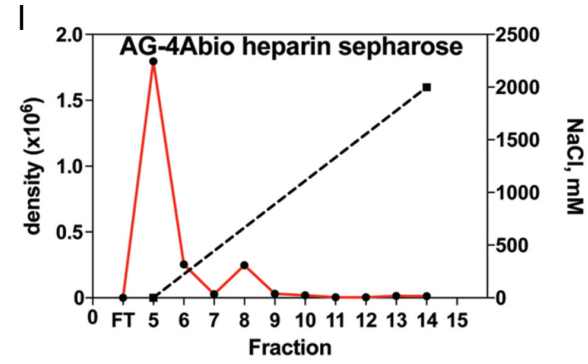

Figure 6

UAG binding to cell surfaces is dependent on interactions between its lysines and cell surface heparan sulfates (HS). (A) Heparinase III treatment reduces cell surface HS (representative FACS plot; surface HS: black, unstained; blue, $\alpha$-mouse PE; red, $\alpha$-HS antibody $+\alpha$-mouse PE). (B) Fluorescence intensity data for heparan sulfates in cells treated \pm heparinase (median FI corrected for APC-streptavidin binding). (C) Heparinase treatment suppresses UAGbio binding (representative FACS plot; UAG binding: black, unstained; blue, APC-streptavidin; green, $2 \mu \mathrm{M}$ UAGbio + APC-streptavidin). (D) Fluorescence intensity data for UAGbio in cells treated \pm heparinase (median Fl corrected for APC-streptavidin binding). Staining for HS and UAGbio was performed simultaneously. Red arrows point to reduction in peaks of fluorescence corresponding to HS and UAG binding. (E and F) UAG with lysines substituted for alanines (UAG-4Abio) has significantly reduced affinity for cell surfaces. (E) Representative FACS plot for binding of different concentrations of UAG-4Abio (unstained: black, blue: APC-streptavidin, orange: $0.2 \mu \mathrm{M}$, red; $2 \mu \mathrm{M}$, green; $20 \mu \mathrm{M}$ ). (F) Comparison of binding of UAGbio with UAG-4Abio (median FI corrected for APC-streptavidin binding; * $P<0.05$ vs UAGbio). Acylated ghrelin binds to MCF7 cells and heparin. (G) Representative FACS plot of MCF7 cells labeled with different concentrations of biotinylated AG (black, unstained; blue, APC-streptavidin; orange, 20 nM AGbio; red, 200 nM AGbio; green, $2 \mu$ M AGbio). ( $\mathrm{H}$ and I) Acylated ghrelin binding to heparin is dependent on the presence of the C-terminal lysines. (H) Binding of biotinylated AG. (I) Markedly reduced binding of biotinylated AG-4A (lysines substituted with alanines). Graphs are data derived from dot blots of samples from FPLC runs using heparin sepharose columns eluted with linear gradients of 0-2 $\mathrm{M} \mathrm{NaCl}$ (dotted line, starting at fraction 5). 

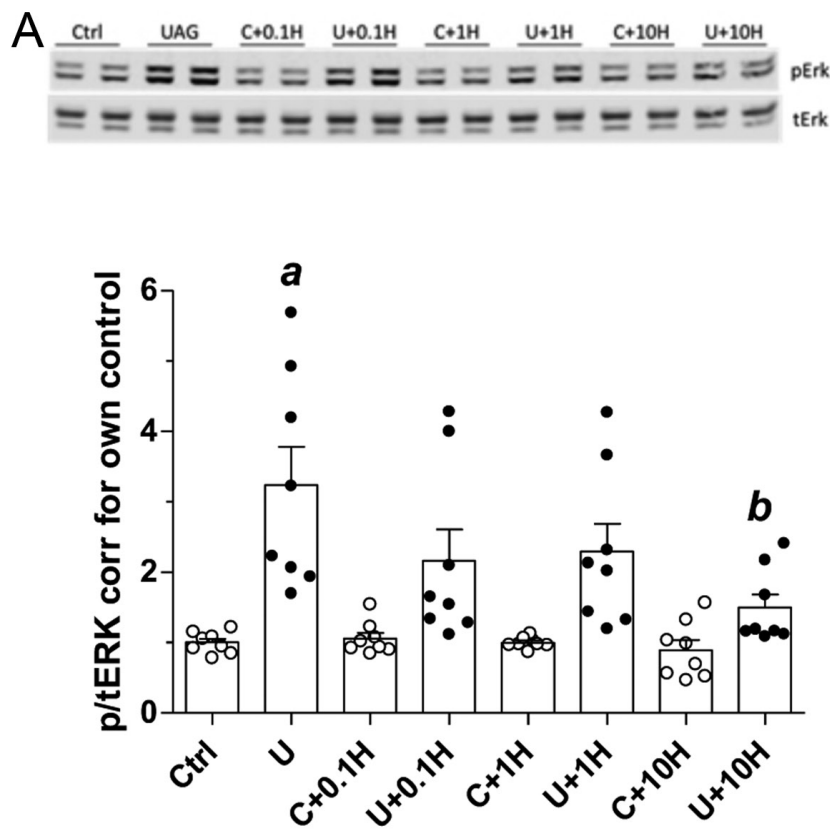

B
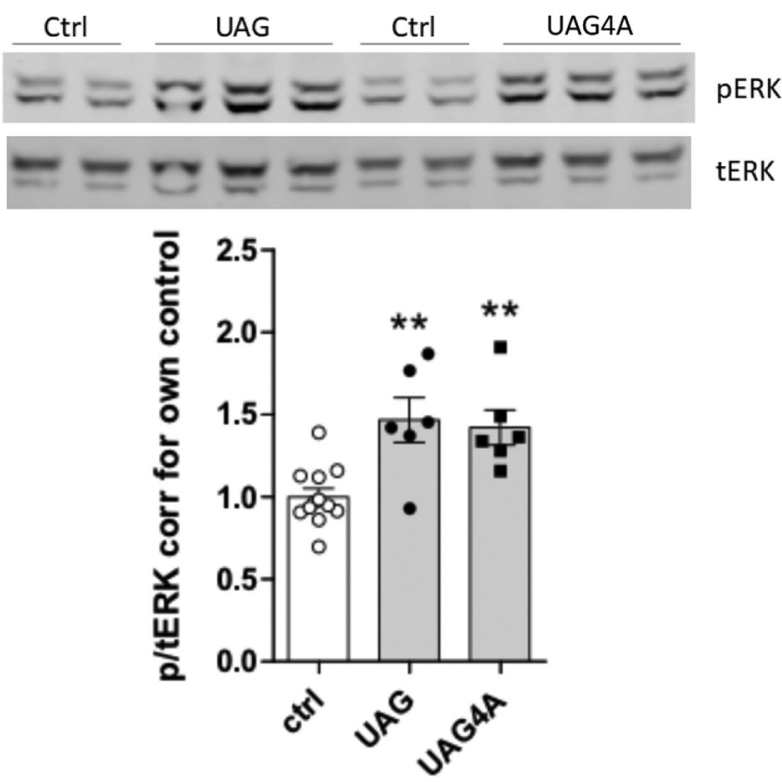

Figure 7

Charge-dependent interactions in activation of ERK by UAG. (A) Heparin dose-dependently suppresses activation of ERK by UAG ( $n=4$ in duplicate) ( ${ }^{P} P<0.001$ vs $C$ trl; ${ }^{b} P<0.01$ vs $U$ ). Representative Western blot of proteins from MCF7 cells treated $\pm 100 \mathrm{nM}$ UAG with increasing concentrations of heparin $(0-10 \mu \mathrm{g} / \mathrm{mL})$, screened simultaneously for phospho and total ERK1/2. Data expressed as the ratio of phospho/total ERK response relative to controls are shown in the graph. (B) UAG-4A induces phosphorylation of ERK in MCF7 cells. MCF7 cells were treated for 5 min with $100 \mathrm{nM}$ peptide ( $n=3$ in duplicate).

be through the remaining arginines (positions 11, 15, 28), or through histidine (position 9). However, $\mathrm{UAG}_{6-13}$ (AZP502), which contains $\mathrm{H} 9$ and R11, bound neither to heparin-sepharose nor to MCF7 cells.
AG has exactly the same peptide sequence as UAG, but is post-translationally octanoylated at Ser3 by GOAT (Gutierrez et al. 2008, Yang et al. 2008). UAG is either released into the circulation in unacylated form, or is generated through the activity of circulating esterases which cleave off the acyl chain (Delhanty et al. 2014). An obvious question for us was whether AG shared UAG's ability to bind heparin and MCF7 cells. Indeed, AG appears to have a similar capacity to bind heparin, and that this interaction is dependent on the C-terminal lysines. In relation to this, others have noted that the strong basic charge of AG could cause it to attach to surfaces making it difficult to quantitate (Liu et al. 2008). In the circulation, AG is bound to triglyceride-rich lipoprotein complexes (Beaumont et al. 2003, Purnell et al. 2003, Patterson et al. 2005, De Vriese et al. 2007). However, these appear to be primarily dependent on lipophilic, not charge-dependent, interactions through its acyl group.

Cell surface binding of biotinylated UAG was detectable in the concentration range that stimulated ERK activation, suggesting a high-affinity interaction, which is also supported by our data showing that relatively high concentrations of salt are required to elute it from heparinsepharose columns. However, we were unable to compete off binding with up to 50x molar excess unlabeled UAG, suggesting that binding sites on the cells were not saturable in the high micromolar range. This is likely because the density of glycans on cell surfaces is so high. Binding of other HSPG binding proteins to cell surfaces has similarly been found to be unsaturable (Jockheck-Clark et al. 2010). This finding is characteristic of the high-capacity interaction observed for cell-surface HSPG ligands due to the extreme abundance of binding sites. However, also characteristic of interactions with HSPGs, we were able to compete off binding of UAG with high concentrations of heparin. The most likely explanation for this effect is that heparin is able to sequester UAG away from the cells and prevent it from binding. This finding likely also explains the effect of heparin in blocking the biological response of MCF7 cells to UAG. Loss of UAG binding through enzymatic removal of cell surface heparan sulfates using heparinase demonstrates the specificity of its interaction with HSPGs.

Because of the importance of HSPGs for the ability of UAG to bind to cell surfaces, it was surprising to us to find that UAG that lacked lysines (UAG-4A) was still able to generate a biological response (activation of ERK). This indicates that, as for many other HSBPs, UAG binding to HS may not serve a direct signaling function, but that absence of binding to HSPGs does not impede its ability 
to activate signaling. An important activity attributed to HSPGs is their ability to tether and present proteins to specific locations in tissues (Xu \& Esko 2014). This is of particular importance, for example, in the regulation of gradients of morphogens and growth factors during development (Poulain \& Yost 2015). We hypothesize that binding of UAG to HSPGs is not mutually exclusive of its impact on signaling, but that HSPGs may be important in directing UAG to its target tissues, and subsequently modulating these effects, as we have shown by modulating the biological response with heparin. It is also likely that UAG interacts with other HSPGs than those identified in MCF7 cells. So, the interaction between UAG and HSPGs is not only involved in signaling, but also the specificity/ localization of this effect.

So, what is the biological significance of the interaction between HSPGs, UAG and ghrelin, particularly in relation to energy homeostasis? HSPGs can all act indirectly as co-receptors that modulate signaling of a range of cytokines through their cell surface receptors (Djordjevic \& Driscoll 2013, Xu \& Esko 2014, Cheng et al. 2016). Recent studies suggest a role for HSPGs in regulating energy balance via the central melanocortin receptoragouti-related protein (MC-AgRP) system (Reizes et al. 2003, Strader et al. 2004, Karlsson-Lindahl et al. 2012, Zhu et al. 2017). AgRP antagonizes the activity of central melanocortin 4 receptors (MC4R) giving it orexigenic properties. Intriguingly, AgRP is also an HS binding protein that binds to syndecan-3 (Madonna et al. 2012, Palomino et al. 2017). Syndecan-3 appears not only to target AgRP to specific regions of the PVN important for its activity, but may also potentiate its activity by concentrating and stabilizing it at these sites. In vivo disruption of syndecan-3 function in mice, either specifically by gene deletion, or generally using heparinase or heparin, leads to a lean phenotype and reduced sensitivity to food deprivation, indicative of an effect on MC4R signaling. HSPGs may facilitate the activity of UAG, but it is interesting to speculate that they also modulate ghrelin's orexigenic, GH secretagogue and other effects via the GHSR in vivo.

\section{Supplementary materials}

This is linked to the online version of the paper at https://doi.org/10.1530/ JME-20-0286.

\section{Declaration of interest}

The authors declare that there is no conflict of interest that could be perceived as prejudicing the impartiality of the research reported.

\section{Funding}

This research did not receive any specific grant from any funding agency in the public, commercial or not-for-profit sector.

\section{Acknowledgements}

The authors thank Dr J M W Martens for providing the MCF7 cell line used in this study. The authors also thank Dr Paul Helbling and Dr Maria Pavlou at DualSystems for their assistance in interpretation of the LRC data, and Dr Mirjam van den Hout (Erasmus Centre for Biomics) and Margreet van Noordergraaf for help with analysis of the RNASeq data.

\section{References}

Au CC, Furness JB, Britt K, Oshchepkova S, Ladumor H, Soo KY, Callaghan B, Gerard C, Inghirami G, Mittal V, et al. 2020 Threedimensional growth of breast cancer cells potentiates the anti-tumor effects of unacylated ghrelin and AZP-531. eLife 9 e56913. (https:// doi.org/10.7554/eLife.56913)

Beaumont NJ, Skinner VO, Tan TM-M, Ramesh BS, Byrne DJ, Maccoll GS, Keen JN, Bouloux PM, Mikhailidis DP, Bruckdorfer KR, et al. 2003 Ghrelin can bind to a species of high-density lipoprotein associated with paraoxonase. Journal of Biological Chemistry 278 8877-8880. (https://doi.org/10.1074/jbc. C200575200)

Bednarek MA, Feighner SD, Pong SS, Mckee KK, Hreniuk DL, Silva MV, Warren VA, Howard AD, Van Der Ploeg LHY \& Heck JV 2000 Structure-function studies on the new growth hormone-releasing peptide, ghrelin: minimal sequence of ghrelin necessary for activation of growth hormone secretagogue receptor 1a. Journal of Medicinal Chemistry 43 4370-4376. (https://doi.org/10.1021/ jm0001727)

Benso A, St-Pierre DH, Prodam F, Gramaglia E, Granata R, Van Der Lely AJ, Ghigo E \& Broglio F 2012 Metabolic effects of overnight continuous infusion of unacylated ghrelin in humans. European Journal of Endocrinology 166 911-916. (https://doi.org/10.1530/EJE11-0982)

Bernfield M, Gotte M, Park PW, Reizes O, Fitzgerald ML, Lincecum J \& Zako M 1999 Functions of cell surface heparan sulfate proteoglycans. Annual Review of Biochemistry 68 729-777. (https://doi.org/10.1146/ annurev.biochem.68.1.729)

Beukel JC, Grefhorst A, Quarta C, Steenbergen J, Mastroberardino PG, Lombès M, Delhanty PJ, Mazza R, Pagotto U, Lely AJ, et al. 2014 Direct activating effects of adrenocorticotropic hormone (ACTH) on brown adipose tissue are attenuated by corticosterone. FASEB Journal 28 4857-4867. (https://doi.org/10.1096/fj.14-254839)

Broglio F, Arvat E, Benso A, Gottero C, Muccioli G, Papotti M, Van Der Lely AJvd, Deghenghi R \& Ghigo E 2001 Ghrelin, a natural GH secretagogue produced by the stomach, induces hyperglycemia and reduces insulin secretion in humans. Journal of Clinical Endocrinology and Metabolism 86 5083-5086. (https://doi.org/10.1210/ jcem.86.10.8098)

Broglio F, Gottero C, Prodam F, Gauna C, Muccioli G, Papotti M, Abribat T, Van Der Lely AJ \& Ghigo E 2004 Non-acylated ghrelin counteracts the metabolic but not the neuroendocrine response to acylated ghrelin in humans. Journal of Clinical Endocrinology and Metabolism 89 3062-3065. (https://doi.org/10.1210/jc.2003031964)

Callaghan B \& Furness JB 2014 Novel and conventional receptors for ghrelin, desacyl-ghrelin, and pharmacologically related compounds. Pharmacological Reviews 66 984-1001. (https://doi.org/10.1124/ pr.113.008433) https://jme.bioscientifica.com

https://doi.org/10.1530/JME-20-0286
(C) 2021 Society for Endocrinology Published by Bioscientifica Ltd. Printed in Great Britain 
Cassoni P, Papotti M, Ghe C, Catapano F, Sapino A, Graziani A, Deghenghi R, Reissmann T, Ghigo E \& Muccioli G 2001 Identification, characterization, and biological activity of specific receptors for natural (ghrelin) and synthetic growth hormone secretagogues and analogs in human breast carcinomas and cell lines. Journal of Clinical Endocrinology and Metabolism 86 1738-1745. (https://doi.org/10.1210/jcem.86.4.7402)

Cassoni P, Ghe C, Marrocco T, Tarabra E, Allia E, Catapano F, Deghenghi R, Ghigo E, Papotti M \& Muccioli G 2004 Expression of ghrelin and biological activity of specific receptors for ghrelin and des-acyl ghrelin in human prostate neoplasms and related cell lines. European Journal of Endocrinology 150 173-184. (https://doi. org/10.1530/eje.0.1500173)

Cheng B, Montmasson M, Terradot L \& Rousselle P 2016 Syndecans as cell surface receptors in cancer biology. A focus on their interaction with PDZ domain proteins. Frontiers in Pharmacology 7 10. (https:// doi.org/10.3389/fphar.2016.00010)

Costantini VJA, Vicentini E, Sabbatini FM, Valerio E, Lepore S, Tessari M, Sartori M, Michielin F, Melotto S, Merlo Pich E, et al. 2011 GSK1614343, a novel ghrelin receptor antagonist, produces an unexpected increase of food intake and body weight in rodents and dogs. Neuroendocrinology 94 158-168. (https://doi. org/10.1159/000328968)

De Vriese C, Hacquebard M, Gregoire F, Carpentier Y \& Delporte C 2007 Ghrelin interacts with human plasma lipoproteins. Endocrinology 148 2355-2362. (https://doi.org/10.1210/en.2006-1281)

Delhanty PJD, Sun Y, Visser JA, Van Kerkwijk A, Huisman M, Van Ijcken WFJ, Swagemakers S, Smith RG, Themmen APN \& Van Der Lely AJ 2010 Unacylated ghrelin rapidly modulates lipogenic and insulin signaling pathway gene expression in metabolically active tissues of GHSR deleted mice. PLOS ONE 5 e11749. (https://doi. org/10.1371/journal.pone.0011749)

Delhanty PJD, Huisman M, Baldeon-Rojas LY, Berge I, Grefhorst A, Abribat T, Leenen PJM, Themmen APN \& Lely A 2013 Des-acyl ghrelin analogs prevent high-fat-diet-induced dysregulation of glucose homeostasis. FASEB Journal 27 1690-1700. (https://doi. $\operatorname{org} / 10.1096 /$ fj.12-221143)

Delhanty PJD, Neggers SJ \& Van Der Lely AJ 2014 Should we consider des-acyl ghrelin as a separate hormone and if so, what does it do? Frontiers of Hormone Research 42 163-174. (https://doi. org/10.1159/000358345)

Djordjevic S \& Driscoll PC 2013 Targeting VEGF signalling via the neuropilin co-receptor. Drug Discovery Today 18 447-455. (https:// doi.org/10.1016/j.drudis.2012.11.013)

Fang F, Shi X, Brown MS, Goldstein JL \& Liang G 2019 Growth hormone acts on liver to stimulate autophagy, support glucose production, and preserve blood glucose in chronically starved mice. PNAS 116 7449-7454. (https://doi.org/10.1073/pnas.1901867116)

Frei AP, Moest H, Novy K \& Wollscheid B 2013 Ligand-based receptor identification on living cells and tissues using TRICEPS. Nature Protocols 8 1321-1336. (https://doi.org/10.1038/nprot.2013.072)

Gauna C, Delhanty PJD, Hofland LJ, Janssen JAMJL, Broglio F, Ross RJM, Ghigo E \& Van Der Lely AJ 2005 Ghrelin stimulates, whereas desoctanoyl ghrelin inhibits, glucose output by primary hepatocytes. Journal of Clinical Endocrinology and Metabolism 90 1055-1060. (https://doi.org/10.1210/jc.2004-1069)

Gauna C, Van De Zande B, Van Kerkwijk A, Themmen APN, Van Der Lely AJ \& Delhanty PJD 2007 Unacylated ghrelin is not a functional antagonist but a full agonist of the type 1a growth hormone secretagogue receptor (GHS-R). Molecular and Cellular Endocrinology 274 30-34. (https://doi.org/10.1016/j.mce.2007.05.010)

Goldstein JL, Zhao T-j, Li RL, Sherbet DP, Liang G \& Brown MS 2011 Surviving starvation: essential role of the ghrelin-growth hormone axis. Cold Spring Harbor Symposia on Quantitative Biology 76 121-127. (https://doi.org/10.1101/sqb.2011.76.010447)
Gutierrez JA, Solenberg PJ, Perkins DR, Willency JA, Knierman MD, Jin Z, Witcher DR, Luo S, Onyia JE \& Hale JE 2008 Ghrelin octanoylation mediated by an orphan lipid transferase. PNAS 105 6320-6325. (https://doi.org/10.1073/pnas.0800708105)

Halem HA, Taylor JE, Dong JZ, Shen Y, Datta R, Abizaid A, Diano S, Horvath TL \& Culler MD 2005 A novel growth hormone secretagogue-1a receptor antagonist that blocks ghrelin-induced growth hormone secretion but induces increased body weight gain. Neuroendocrinology 81 339-349. (https://doi.org/10.1159/000088796)

Heppner KM, Piechowski CL, Muller A, Ottaway N, Sisley S, Smiley DL, Habegger KM, Pfluger PT, Dimarchi R, Biebermann H, et al. 2014 Both acyl and des-acyl ghrelin regulate adiposity and glucose metabolism via CNS ghrelin receptors. Diabetes 63 122-131. (https:// doi.org/10.2337/db13-0414)

Hopkins AL, Nelson TAS, Guschina IA, Parsons LC, Lewis CL, Brown RC, Christian HC, Davies JS \& Wells T 2017 Unacylated ghrelin promotes adipogenesis in rodent bone marrow via ghrelin $\mathrm{O}$-acyl transferase and GHS-R1a activity: evidence for target cell-induced acylation. Scientific Reports 7 45541. (https://doi.org/10.1038/srep45541)

Jockheck-Clark AR, Bowers EV, Totonchy MB, Neubauer J, Pizzo SV \& Nicchitta CV 2010 Re-examination of CD91 function in GRP94 (glycoprotein 96) surface binding, uptake, and peptide crosspresentation. Journal of Immunology 185 6819-6830. (https://doi. org/10.4049/jimmunol.1000448)

Karlsson-Lindahl L, Schmidt L, Haage D, Hansson C, Taube M, Egecioglu E, Tan YX, Admyre T, Jansson JO, Vlodavsky I, et al. 2012 Heparanase affects food intake and regulates energy balance in mice. PLoS ONE 7 e34313. (https://doi.org/10.1371/journal. pone.0034313)

Knelson EH, Nee JC \& Blobe GC 2014 Heparan sulfate signaling in cancer. Trends in Biochemical Sciences 39 277-288. (https://doi. org/10.1016/j.tibs.2014.03.001)

Kojima M, Hosoda H, Date Y, Nakazato M, Matsuo H \& Kangawa K 1999 Ghrelin is a growth-hormone-releasing acylated peptide from stomach. Nature 402 656-660. (https://doi.org/10.1038/45230)

Li C, Wen A, Shen B, Lu J, Huang Y \& Chang Y 2011 FastCloning: a highly simplified, purification-free, sequence- and ligationindependent PCR cloning method. BMC Biotechnology 1192. (https://doi.org/10.1186/1472-6750-11-92)

Liu J, Prudom CE, Nass R, Pezzoli SS, Oliveri MC, Johnson ML, Veldhuis P, Gordon DA, Howard AD, Witcher DR, et al. 2008 Novel ghrelin assays provide evidence for independent regulation of ghrelin acylation and secretion in healthy young men. Journal of Clinical Endocrinology and Metabolism 93 1980-1987. (https://doi. org/10.1210/jc.2007-2235)

Madonna ME, Schurdak J, Yang YK, Benoit S \& Millhauser GL 2012 Agouti-related protein segments outside of the receptor binding core are required for enhanced short- and long-term feeding stimulation. ACS Chemical Biology 7 395-402. (https://doi.org/10.1021/ cb2003412)

Muller TD, Nogueiras R, Andermann ML, Andrews ZB, Anker SD, Argente J, Batterham RL, Benoit SC, Bowers CY, Broglio F, et al. 2015 Ghrelin. Molecular Metabolism 4 437-460. (https://doi.org/10.1016/j. molmet.2015.03.005)

Mythreye K \& Blobe GC 2009 Proteoglycan signaling co-receptors: roles in cell adhesion, migration and invasion. Cellular Signalling 21 1548-1558. (https://doi.org/10.1016/j.cellsig.2009.05.001)

Palomino R, Lee HW \& Millhauser GL 2017 The agouti-related peptide binds heparan sulfate through segments critical for its orexigenic effects. Journal of Biological Chemistry 292 7651-7661. (https://doi. org/10.1074/jbc.M116.772822)

Patterson M, Murphy KG, Le Roux CW, Ghatei MA \& Bloom SR 2005 Characterization of ghrelin-like immunoreactivity in human plasma. Journal of Clinical Endocrinology and Metabolism 90 2205-2211. (https://doi.org/10.1210/jc.2004-1641) 
Poulain FE \& Yost HJ 2015 Heparan sulfate proteoglycans: a sugar code for vertebrate development? Development 142 3456-3467. (https:// doi.org/10.1242/dev.098178)

Purnell JQ, Weigle DS, Breen P \& Cummings DE 2003 Ghrelin levels correlate with insulin levels, insulin resistance, and high-density lipoprotein cholesterol, but not with gender, menopausal status, or cortisol levels in humans. Journal of Clinical Endocrinology and Metabolism 88 5747-5752. (https://doi.org/10.1210/jc.2003-030513)

Reizes O, Benoit SC, Strader AD, Clegg DJ, Akunuru S \& Seeley RJ 2003 Syndecan-3 modulates food intake by interacting with the melanocortin/AgRP pathway. Annals of the New York Academy of Sciences 994 66-73. (https://doi.org/10.1111/j.1749-6632.2003. tb03163.x)

Sarrazin S, Lamanna WC \& Esko JD 2011 Heparan sulfate proteoglycans. Cold Spring Harbor Perspectives in Biology 3 a004952-a004952. (https:// doi.org/10.1101/cshperspect.a004952)

Soker S, Takashima S, Miao HQ, Neufeld G \& Klagsbrun M 1998 Neuropilin-1 is expressed by endothelial and tumor cells as an isoform-specific receptor for vascular endothelial growth factor. Cell 92 735-745. (https://doi.org/10.1016/S0092-8674(00)81402-6)

Strader AD, Reizes O, Woods SC, Benoit SC \& Seeley RJ 2004 Mice lacking the syndecan-3 gene are resistant to diet-induced obesity.
Journal of Clinical Investigation 114 1354-1360. (https://doi. org/10.1172/JCI20631)

Tine M, Kuhl H, Teske PR, Tschop MH \& Jastroch M 2016 Diversification and coevolution of the ghrelin/growth hormone secretagogue receptor system in vertebrates. Ecology and Evolution 6 2516-2535. (https://doi.org/10.1002/ece3.2057)

Xu D \& Esko JD 2014 Demystifying heparan sulfate-protein interactions. Annual Review of Biochemistry 83 129-157. (https://doi.org/10.1146/ annurev-biochem-060713-035314)

Yang J, Brown MS, Liang G, Grishin NV \& Goldstein JL 2008 Identification of the acyltransferase that Octanoylates ghrelin, an appetite-stimulating peptide hormone. Cell 132 387-396. (https:// doi.org/10.1016/j.cell.2008.01.017)

Zheng AP, Kallio A \& Harkonen P 2007 Tamoxifen-induced rapid death of MCF-7 breast cancer cells is mediated via extracellularly signal-regulated kinase signaling and can be abrogated by estrogen. Endocrinology 148 2764-2777. (https://doi.org/10.1210/ en.2006-1269)

Zhu CJ, Xu PW, He YL, Yuan YX, Wang T, Cai XC, Yu LL, Yang LS, Wu JG, Wang L, et al. 2017 Heparin increases food intake through AgRP neurons. Cell Reports 20 2455-2467. (https://doi.org/10.1016/j. celrep.2017.08.049)

Received in final form 21 October 2020

Accepted 26 November 2020

Accepted Manuscript published online 3 December 2020
(C) 2021 Society for Endocrinology Published by Bioscientifica Ltd. Printed in Great Britain 